\section{To: (Receiving Organization) Distribution}

5. Proj./Prog./Dept./Div.:

Spent Nuclear Fuel Project

8. Originator Remarks:

For approval and information

3. From: (Originating Organization)

SNF Characterization

Project/2T72D

6. Design Authority/ Design Agent/Cog. Engr.:
4. Related EDT No.:

7. Purchase Order No.:

$\mathrm{N} / \mathrm{A}$

9. Equip./Component No.:

$\mathrm{N} / \mathrm{A}$

10. System/Bldg./Facility:

$\mathrm{K}$ Basins/100K

11. Receiver Remarks: 11A. Design Baseline Document? [] Yes [X] No

12. Major Assm. Dwg. No.:
$\mathrm{N} / \mathrm{A}$

13. Permit/Permit Application No.:

$N / A$

14. Required Response Date: $N / A$

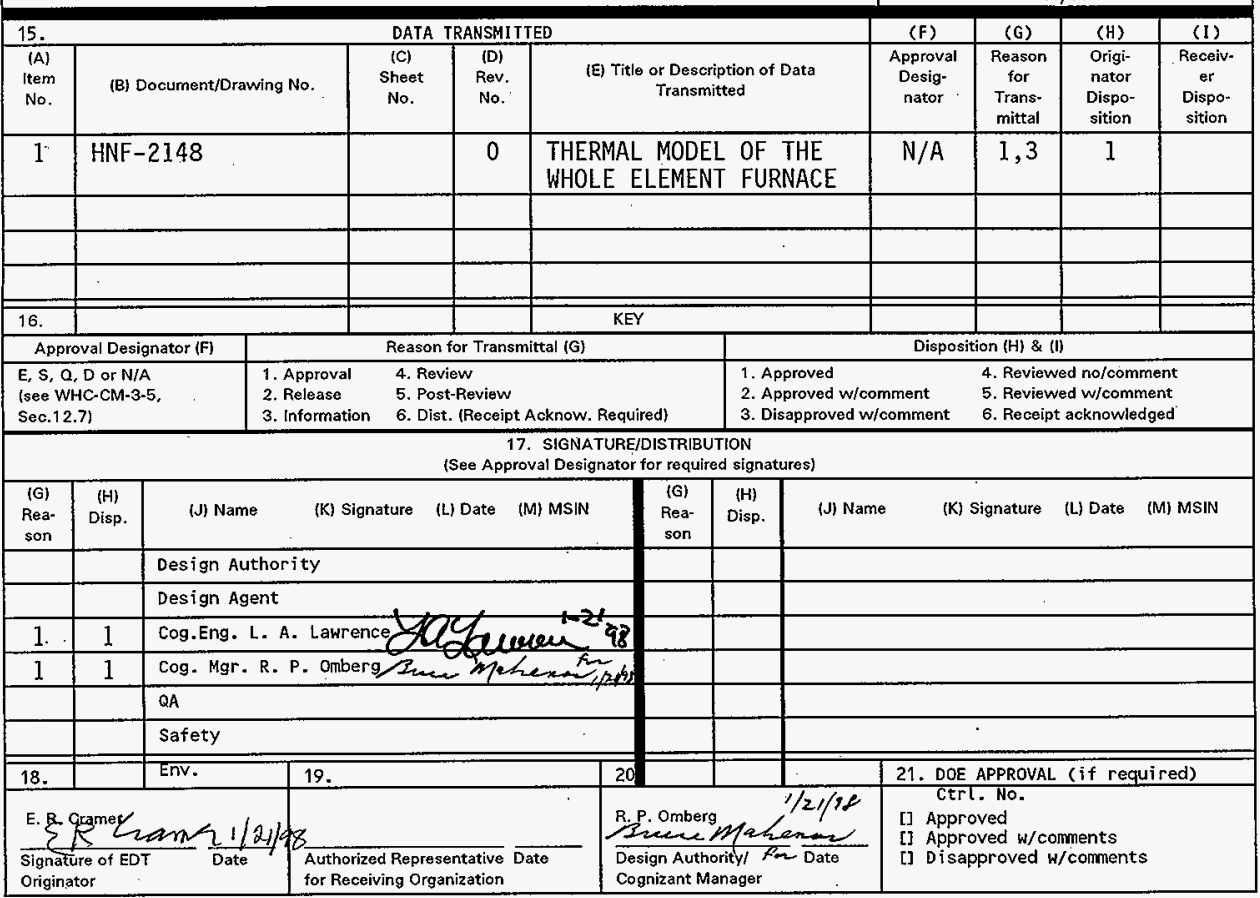




\title{
THERMAL MODEL OF THE WHOLE ELEMENT FURNACE
}

\author{
E. R. Cramer
}

Numatec Hanford Company, Richland, WA 99352

U.S. Department of Energy Contract DE-AC06-96RL13200

$\begin{array}{lll}\text { EDT/ECN: } & 608766 & \text { UC: 2070 } \\ \text { Org Code: } & 8 \mathrm{C} 453 & \text { Charge Code: LB026 } \\ \text { B\&R Code: } & \text { EW7040000 } & \text { Total Pages: } 18\end{array}$

Key Words: Thermal Analysis, Whole Element Furnace Test, 105-K Basins, Spent Nuclear Fuel

Abstract: A detailed thermal analysis was performed to calculate temperatures in the whole element test furnace that is used to conduct drying studies of $\mathrm{N}$-Reactor fuel. The purpose of this analys is was to estabiish the thermal characteristics of the test system and to provide a basis for post-test analysis.

TRADEMARK DISCLAIMER. Reference herein to any specific comercial product, process, or service by trade name, trademark, manufacturer, or otherwise, does not necessarily constitute or imply its endorsement, recommendation; or favoring by the United States Government or any agency thereof or its contractors or subcontractors.

Printed in the United States of America. To obtain coptes of this document, contact: Docuifient Control Services, P.0. Box 950, Mailstop H6-08, Richland WA 99352, Phone (509) 372-2420
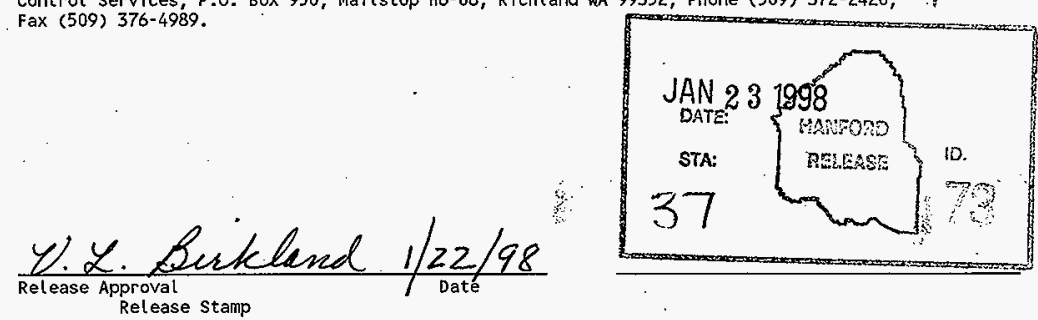
THERMAL MODEL OF THE WHOLE ELEMENT FURNACE

January 1998

by

E. R. Cramer

Numatec Hanford Corporation

P. 0. box 1500

Richland, Washington

99352- 1500

Prepared for the

U.S. Department of Energy

Richland Operations office

Richland, Washington 
HNF-2148, Rev. 0

THERMAL MODEL OF THE WHOLE ELEMENT FURNACE

\subsection{INTRODUCTION}

A three-dimensional thermal model was constructed of an N-Reactor outer fuel element in the whole element furnace located in the 327 building hot cells. This furnace is being utilized for low and high temperature drying studies of damaged $\mathrm{N}$-Reactor fuel elements stored in the K-East and K-West basins. The thermal model was used to calculate the temperature distribution in a fuel element in the furnace for a variety of input parameters. The purpose of this analysis was to establish the thermal characteristics of the test system and to provide a basis for post-test analysis and modeling studies.

The drying tests are conducted in a furnace at $300{ }^{\circ} \mathrm{C}$ with a small amount of argon gas flowing through the test section. The fuel element sits on a boat. which is inside a 4 -in. diameter retort tube inside the furnace. The fuel elements selected for the tests were only the outer element of the $\mathrm{N}$-Reactor fuel and had corrosion only on the ends.

\subsection{RESULTS}

Eleven cases were analyzed with this model. A general view of the temperature results is shown in Figures 1 and 2. Al1 eleven cases show the same general results, but with different actual temperatures calculated for the fuel element. Three general observations can be made about the fuel element in the test furnace from these results. .

1. The fuel element acts like a heat transfer fin, conducting heat generated at the corroded ends to the middle of the fuel element.

2. Thermal radiation is the dominant heat transfer mechanism from the fuel element to the retort tube.

3. When the heat generation rate is higher than the heat removal rate at any temperature, there is no analytical solution to this model and the fuel element temperature will continue to increase without limit (according to the model).

The results of this work indicate that the critical temperature for a runaway temperature excursion to occur in the furnace is about $348^{\circ} \mathrm{C}$. Actually, the uranium-oxygen reaction would be oxygen limited at high temperatures and the model of the heat generation rate used in this analysis would not apply. No attempt was made to model oxygen limited reactions in this analysis.

For most of the analyzed cases, the heat from the oxidation reaction was assumed to be generated only on the end surface of the fuel element. For two 
HNF-2148, Rev. '0

cases some additional heat was also assumed to be generated along the inside and outside surfaces of the fuel near the corroded end. The heat is readily conducted from the ends toward the middle of the fuel element due to the high conductivity of uranium.

The heat is transferred from the fuel element to the retort tube predominantly by thermal radiation. There is some heat transfer by conduction through the boat to the retort tube and an even smaller amount of heat transfer by conduction through the-argon gas. The retort tube is cooled by conduction and radiation to the furnace which is presumed to be held at $300{ }^{\circ} \mathrm{C}$.

The maximum fuel element temperatures calculated for each of nine cases are shown in Table 1. A side view of the fuel element showing the calculated temperature results are shown in Figures 3 through 9.

Table 1. Maximum Calculated Fuel Element Temperatures.

\begin{tabular}{|c|c|c|}
\hline Case & Description & $\begin{array}{l}\text { Max Fuel Temperature, } \\
{ }^{\circ} \mathrm{C}\end{array}$ \\
\hline I & $\begin{array}{l}\text { Abrefah et a1. (1996) oxidation heat on } \\
\text { fuel end surface }\end{array}$ & 305.1 \\
\hline 2 & $\begin{array}{l}2 \times \text { Abrefah et a1. (1996) oxidation heat } \\
\text { on fuel end surface }\end{array}$ & 311.2 \\
\hline 3 & $\begin{array}{l}4 \times \text { Abrefah et a1. (1996) oxidation heat } \\
\text { on fuel end surface }\end{array}$ & 337.5 \\
\hline 4 & $\begin{array}{l}5 \times \text { Abrefah et a1. (1996) oxidation heat } \\
\text { on fuel end surface }\end{array}$ & No solution \\
\hline 5 & $\begin{array}{l}\text { Same as Case } 2 \text { except fuel element } \\
\text { emissivity is reduced to } 0.5 \text { (from } 0.7 \text { ) }\end{array}$ & 312.3 \\
\hline 6 & $\begin{array}{l}\text { Same as Case } 2 \text { except no heat transfer } \\
\text { from fuel end surface }\end{array}$ & 312.3 \\
\hline 7 & $\begin{array}{l}\text { Trimble and Welsh, (1998) oxidation heat } \\
\text { on fuel end surface }\end{array}$ & 311.0 \\
\hline 8 & $\begin{array}{l}\text { Trimble and Weish, (1998) oxidation heat } \\
\text { on fuel end surface and } 0.1 \times \text { Trimble and } \\
\text { Welsh, (1998) heat on } 3-i n \text {. of inside and } \\
\text { outside fuel surface }\end{array}$ & 344.7 \\
\hline 9 & $\begin{array}{l}\text { Trimble and Welsh, (1998) oxidation heat } \\
\text { on fuel end surface and } 0.25 \times \text { Trimble and } \\
\text { Welsh, (1998) heat on } 3-i n \text {. of inside and } \\
\text { outside fuel surface }\end{array}$ & No solution \\
\hline
\end{tabular}

The first six cases in Table 1 used Abrefah's et al (1996) regression fit of oxidation data (Abrefah et a1. 1996) described in Section 3. Case 1 used the Abrefah et a1. (1996) rate without a multiplier and Cases 2, 3, and 4 used the Abrefah et a1. (1996) rate times a multiplier of 2, 4, and 5 respectively. In Case 2, the fuel end surface temperature was $311.2{ }^{\circ} \mathrm{C}$. At this temperature 
the heat generation rate is 1.14 times the heat generation rate at $305.1{ }^{\circ} \mathrm{C}$, so the actual heat generation rate used in Case 2 is 1.14 times the multiplier of 2 , or 2.28 times that of Case 1 .

In Case 3, the Abrefah et a1. (1996) rate was multiplied by 4 and the calculated fuet end surface temperature was $337.5^{\circ} \mathrm{C}$. At this temperature the heat generation rate from Abrefah et al. (1996) is 1.99 times the heat generation rate used in Case 1 . The actual heat generation rate used in case 3 is then 1.99 times 4 , or 7.96 times the rate used in Case 1 .

No solution could be reached for Case 4 with a multiplier of 5 on the heat generation rate. This indicates that 5 times the heat generation rate is higher than the heat removal rate for any. temperature and no analytical solution exists to this model.

In Case 5 , the sensitivity to fuel element emissivity was studied by reducing the fuel emissivity to 0.5 . All other cases used 0.7 . This increased the maximum fuel temperature by only $1.1^{\circ} \mathrm{C}$. A multiplier of 2 was used on the heat generation rate for this case.

Case 6 considered the possibility of corrosion products forming a barrier to heat transfer from the fuel. To simulate this effect the emissivity and the heat transfer coefficient on the fuel end surface were set to zero. other parameters were the same as in Case 2. This was found to increase the maximum fuel temperature by $1.1{ }^{\circ} \mathrm{C}$, from $311.2{ }^{\circ} \mathrm{C}$ to $312.3{ }^{\circ} \mathrm{C}$. This effect is quite small because the area of the fuel end surface is only $15.1 \mathrm{~cm}^{2}$.

Case 7 used the heat generation rate from Trimble and Welsh (1998) which is the upper bound equation for oxidation of uranium in dry air, as described in Section 3. The heat generation was applied to the fuel element end surface only.

Case 8 used the same heat generation on the fuel end surface as in Case 7 , plus 0.1 times the Trimble and Welsh (1998) heat generation along $3-$ in. of the inside and outside surface that is adjacent to the corroded end. The area of the inside and outside surface where the heat was applied is $251 \mathrm{~cm}^{2}$, as compared to $15.1 \mathrm{~cm}^{2}$ on the end surface. As shown in Figure 9 , the temperature at the end of the fuel element is higher than along the sides, so the heat generation per unit area is much larger on the end than along the sides.

Case 9 is the same as Case 8, except that the heat generation multiplier along the sides is 0.25 instead of 0.1 . There was no solution to this case, indicating that the total heat generation is higher than the heat removal rate. 
HNF-2148, Rev. '0

\subsection{DESCRIPTION OF COMPUTER MODEL}

The computer model is a three-dimensional finite element thermal model with about 9,000 nodes. One half of the fuel element length was modeled because of symmetry. The fue element sits on a boat which is inside a 4-in. diameter retort tube. The boat, retort tube, and the argon gas within the retort tube were also modeled. The furnace surrounding the retort tube was not modeled.

The thermal model was developed by the use of the PATRAN model program (PDA 1991) and solved with associated programs P/THERMAL and P/VIEWFACTOR. These programs are al1 proprietary products of the MacNeal-Schwendler $C_{0}$. that have been validated for use at Hanford (Valdiviez 1991). PATRAN was used for pre- and post-processing. It is a geometry model builder with the capability to define associated boundary conditions in a discretized fashion that can be used by an analysis code. P/Thermal was used as the finite element thermal solver that transforms the finite element based problem description from PATRAN into an equivalent network description. It has the capability to add other heat transfer boundary conditions such as thermal radiation to the model description. P/VIEWFACTOR is an adjunct program to P/THERMAL that defines radiation view factors based solely on geometric considerations. The view factors are defined based on the discretized geometry developed by PATRAN.

Heat from a uranium oxidation reaction was assumed to be generated on the end surface of the fuel element. The model also allows heat to be applied to the inside or outside surface of the element along 3-in. of the length near the corroded end. Two oxidation rate equations were used for the various cases that were analyzed with this model. The first is from J. Abrefah's regression fit of uranium oxidation data (Abrefah et a1. 1996):

$$
K=1.44 \times 10^{5} \exp (-14.92 / \mathrm{RT}) \mathrm{mg} / \mathrm{cm}^{2} / \mathrm{min}
$$

where the activation energy of 14.92 is in $\mathrm{kcal} / \mathrm{mole}, \mathrm{R}$ is the gas constant and $T$ is the absolute temperature.

The second equation that was used is:

$$
K=1.733 \times 10^{6} \exp (-8567.5 / \mathrm{T}) \mathrm{mg} / \mathrm{cm}^{2} / \mathrm{min}
$$

where $T$ is the temperature in Kelvin. This is an upper bound equation from an independent reexamination (Trimble and Welsh 1998) of the same uranium oxidation data reported in Abrefah et a1. (1996). A heat of reaction of 3.395 $\times 10^{7}$ Joules $/ \mathrm{Kg}-\mathrm{O}_{2}$ was used.

The finite element mesh used in the model is shown in Figure 10. The finite elements get smaller near the fuel surfaces where the heat from the oxidation reaction is applied. The finite element thickness at the fuel surface is 0.020 in. The oxidation heat is actually applied in one half of the element thickness, i.e., in the 0.010 in. thick volume adjacent to the surface:

The fuel element was also assumed to have a decay heat of 1.3 Watts, deposited uniformly over the fuel volume. 
HNF-2148, Rev. 0

Radiation heat transfer is modeled between all surfaces of the fuel element; boat, and retort tube. View factors were calculated from every node in the model to every other node that is within a line of sight. This includes the inside surface of the fuel element which has some radiation view factor with the retort tube. An emissivity of 0.7 was used for all surfaces. The Spent Nuclear Fuel Project Technical Databook (Short and Beary 1995) recommends an emissivity of 0.7 for uranium.

Argon gas is flowing through the retort tube at approximately $250 \mathrm{cc} / \mathrm{min}$ and is at the retort tube temperature of $300{ }^{\circ} \mathrm{C}$ when it reaches the fuel element: Because of the low flow rate, the argon does not remove any significant heat from the fuel element. Accordingly, it is modeled as a stagnant gas. Conductivity data for argon were obtained from ORNL (1987) as a function of temperature. The thermal conductivity of gases is independent of pressure at pressures above a few torr for the furnace geometry.

The fuel element is in line contact with the boat and the boat is in contact with the retort tube along two lines. The model forces the temperature of the nodes along the lines of contact to be equal for both components. This effectively makes the area of contact equal to the width of one finite element. For the fuel to boat contact this width is $0.115 \mathrm{in}$. and for the boat to retort tube contact it is 0.312 in.

The furnace is presumed to maintain a uniform temperature of $300{ }^{\circ} \mathrm{C}$ around the retort tube. The retort tube is in thermal contact with this boundary condition by thermal radiation and by conduction through the air surrounding the retort tube. An emissivity of 0.7 was used for the retort tube and the conduction was modeled as a convection coefficient of $1.0 \mathrm{Btu} / \mathrm{hr}-\mathrm{ft}^{2}-\mathrm{F}\left(5.67 \mathrm{~W} / \mathrm{m}^{2}-\mathrm{C}\right)$.

The analytical model does not include the part of the retort tube that extends beyond where the fuel element is located. Radiation heat transfer to this part of the retort tube is modeled by assuming the retort tube to be at the boundary condition temperature of $300^{\circ} \mathrm{C}$.

Material properties for the uranium fuel element were obtained from Short and Beary (1995). Material properties for the inconel boat and retort tube were obtained from ORNL (1987). 
HNF-2148, Rev. 0

\subsection{REFERENCES}

J. Abrefah, H. R. Buchanan, and S. C. Marschman, 1996, Highlight Report: Oxidation Kinetics of K-West Spent Nuclear Fuel in Dry Air, SNFCT97:004, Pacific Northest National Laboratory, Richland, Washington.

D. J. Trimble and T. L. Welsh; 1998, Statistical Analysis of Oxidation Rates for $K$ Basin Fuel In Dry Air, HNF-SD-SNF-CN-U35, Richland, Washington.

Patron P7us User Manual, 1991, Release 2.5, PDA Engineering, Costa Mesa, Cal ifornia,

R. Valdiviez, 1991, Verification Report for the P/Thermal Computer Code, WHCSD-GN-CSWD-319, Revision 0, Westinghouse Hanford Company, Richland, Washington.

S. M. Short and M. M. Beary, 1995, Spent Nuc7ear Fue7 Project Technical Databook, WHC-SD-SNF-TI-015, Westinghouse Hanford Company, Richland, Washington.

Nuclear Systems Materials Handbook, 1987, TID2666, Oak Ridge National Laboratory, Tennessee. 


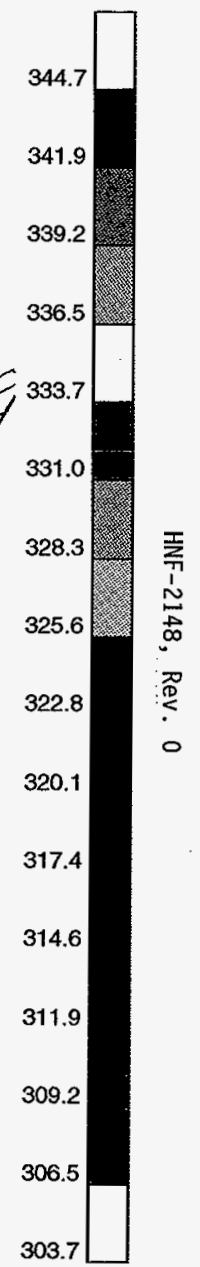

Figure 1. Fuel Element and Boat Temperature Results, ${ }^{\circ} \mathrm{C}$ 


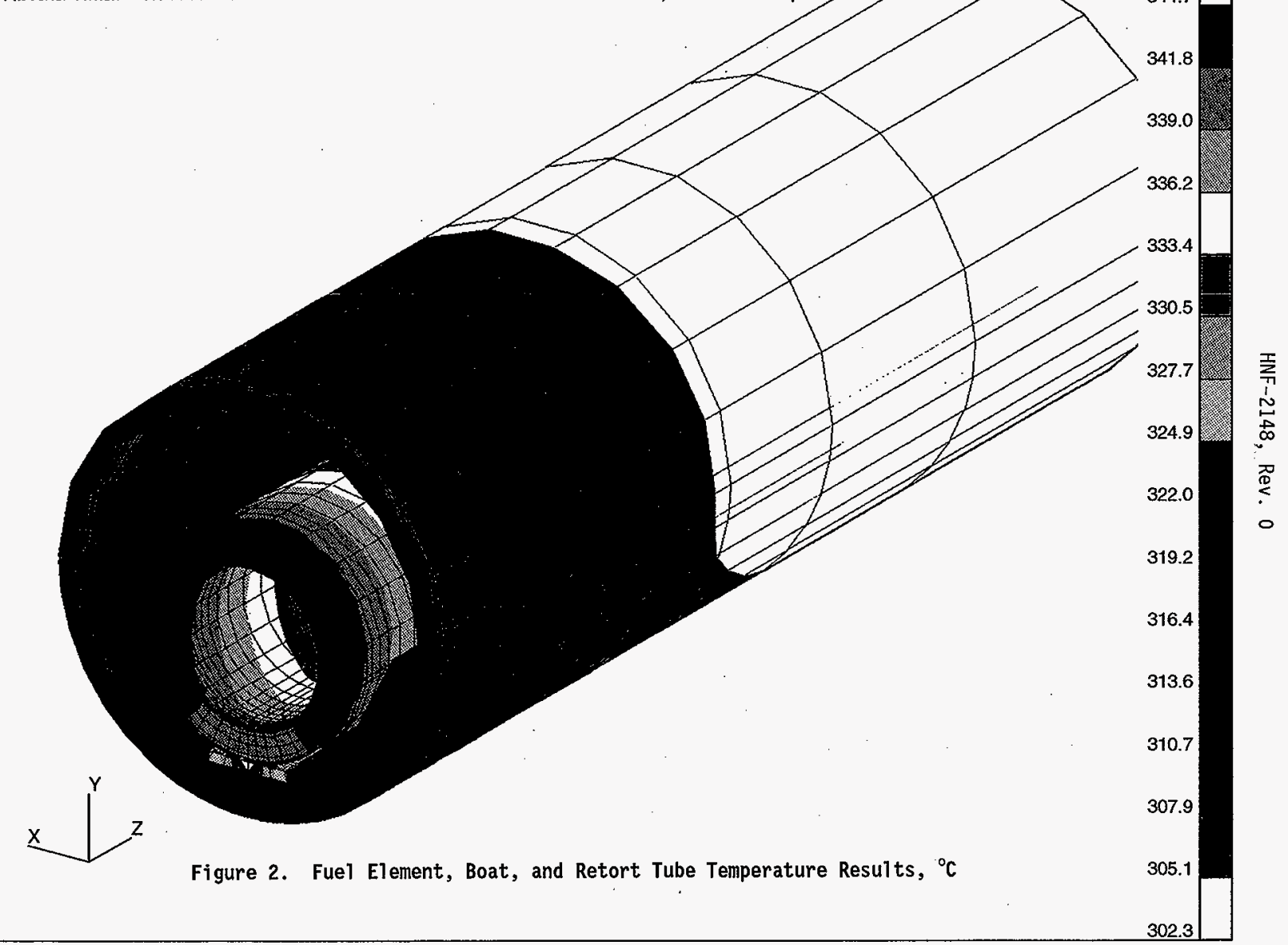




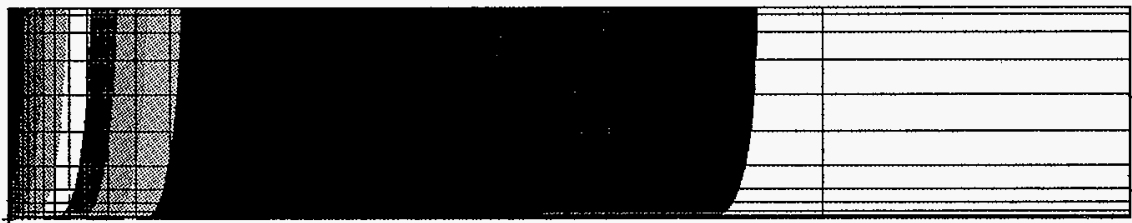

304.5

303.6

Figure 3. Case 1 Temperature Results, ${ }^{\circ} \mathrm{C}$ 


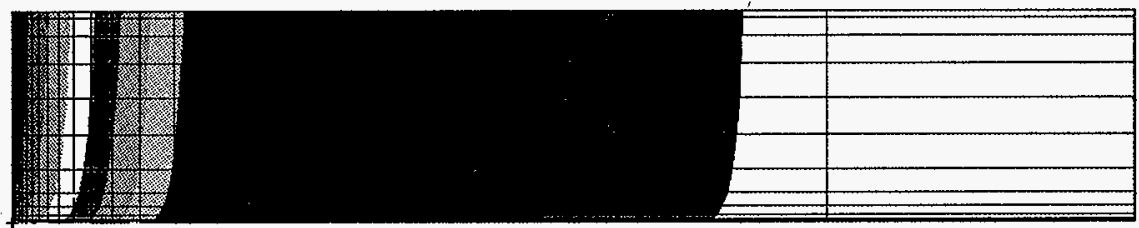




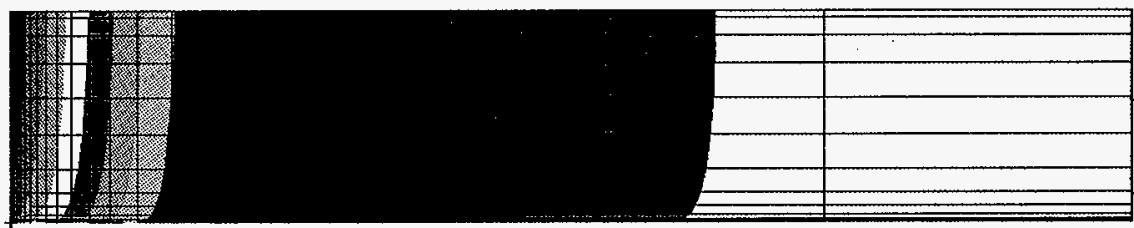

326.4

Figure 5. Case 3 Temperature Results, ${ }^{\circ} \mathrm{C}$ 


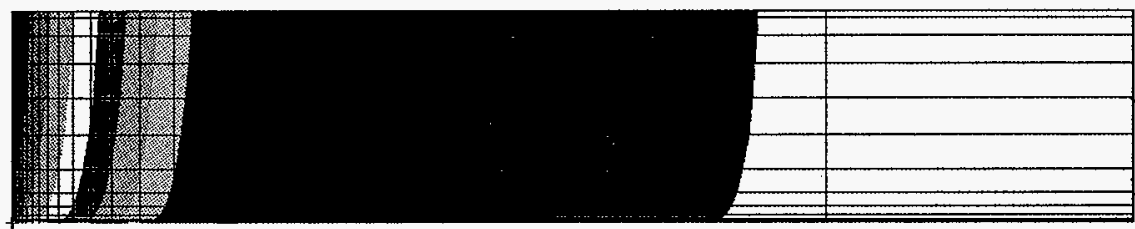

Figure 6. Case 5 Temperature Results, ${ }^{\circ} \mathrm{C}$

Fuel Element Side View

302.8 
HNF-2148, Rev. 0

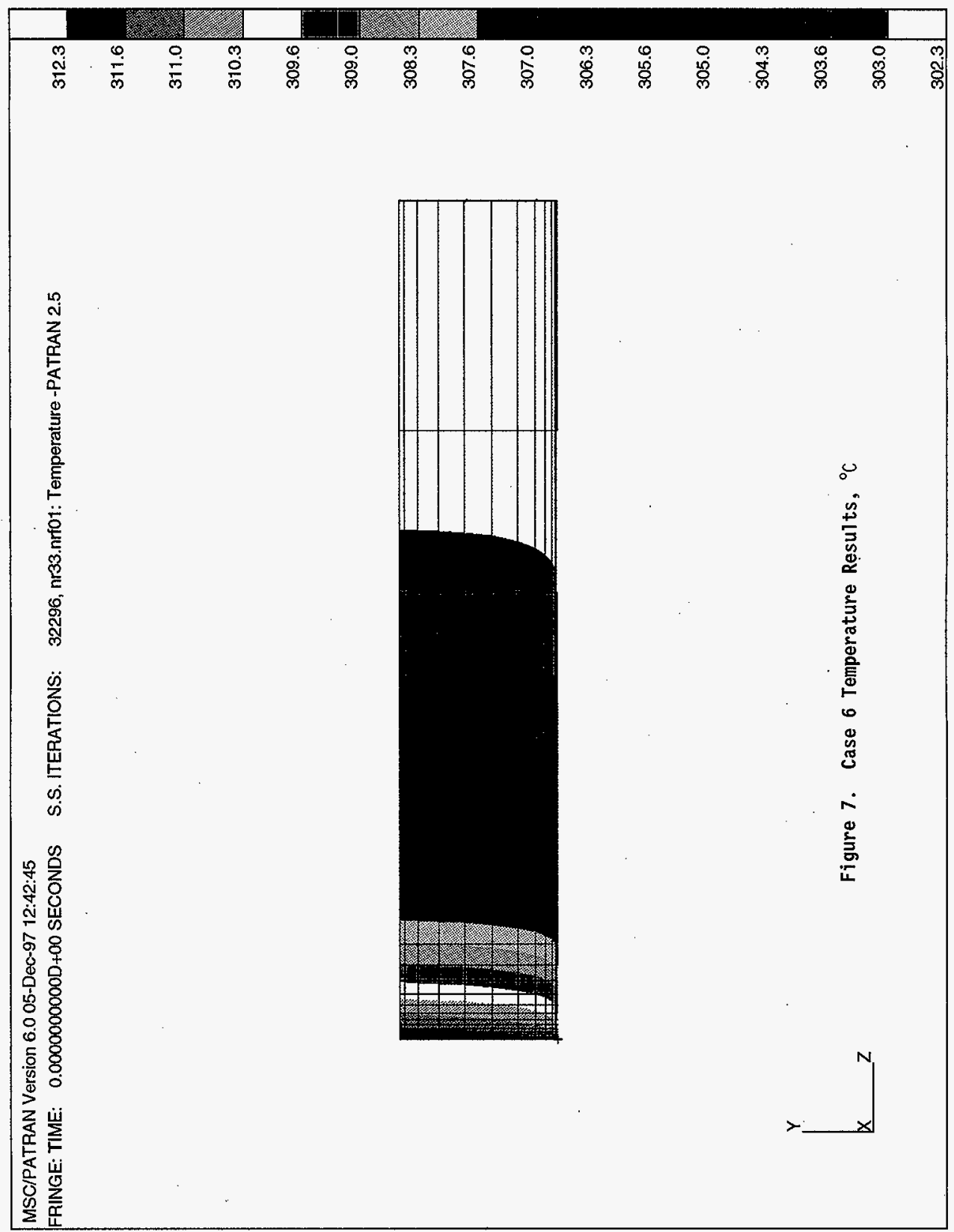




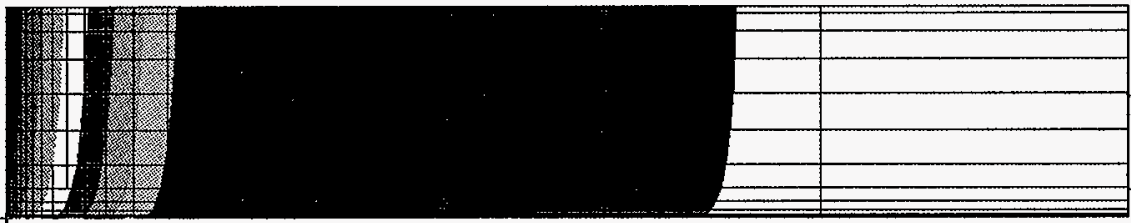

309.0

308.4

307.7

305.8

305.1

Figure 8. Case 7 Temperature Results, ${ }^{\circ} \mathrm{C}$ 


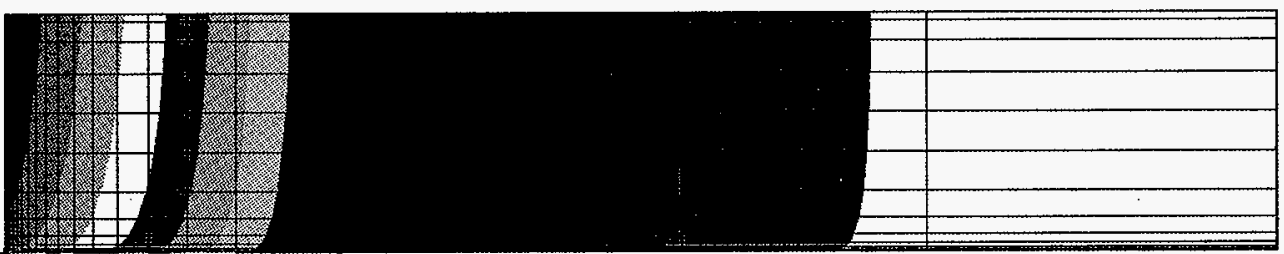
Fuel Element Side View 


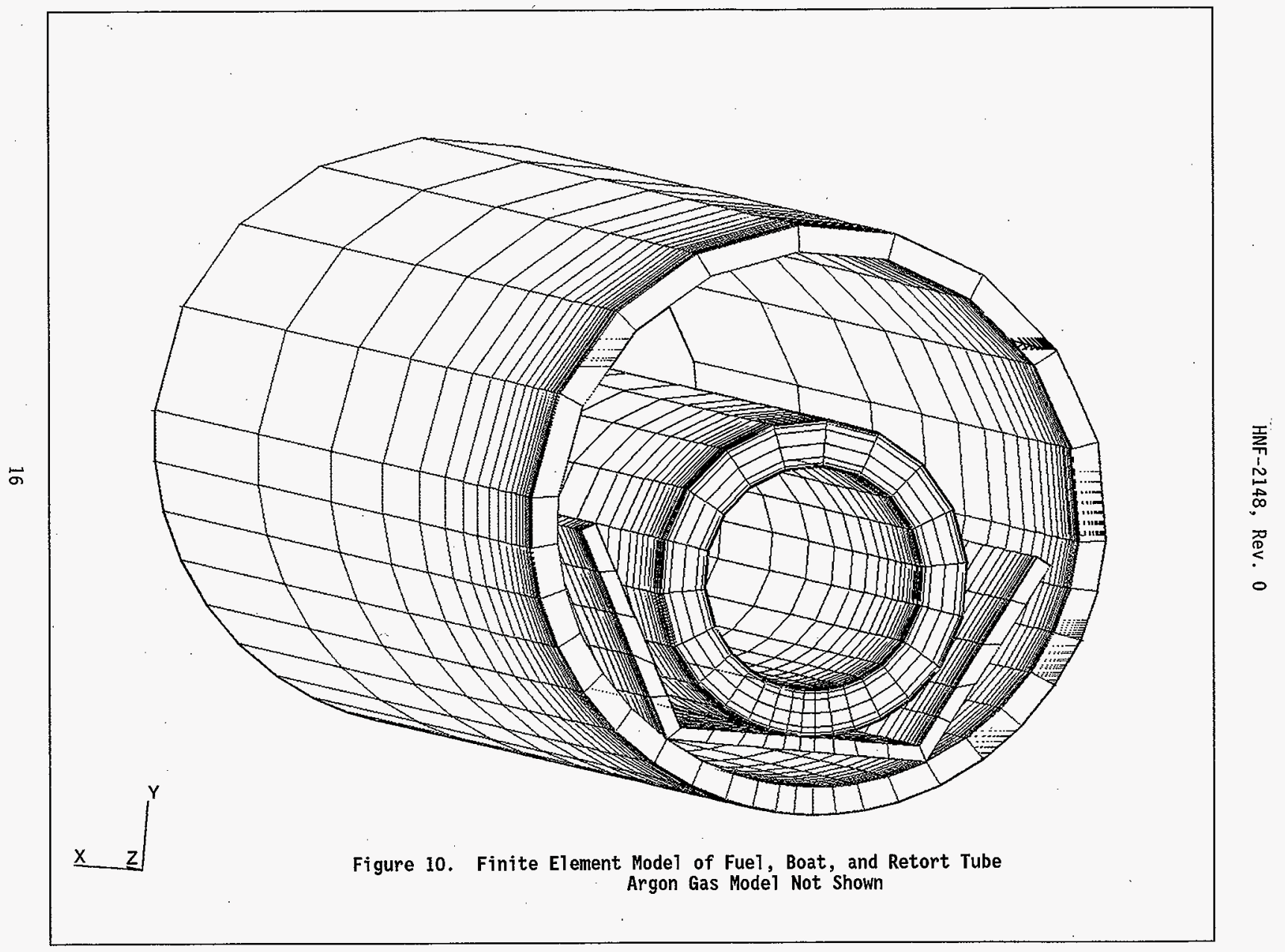




\section{DISTRIBUTION SHEET}

\begin{tabular}{|c|c|c|c|c|c|}
\hline \multirow{2}{*}{$\begin{array}{l}\text { To } \\
\text { Distribution }\end{array}$} & \multirow{2}{*}{\multicolumn{3}{|c|}{$\begin{array}{l}\text { From } \\
\text { SNF Characterjzation } \\
\text { Project } / 8 \mathrm{C} 453\end{array}$}} & \multicolumn{2}{|l|}{ Page 1 of 1} \\
\hline & & & & \multicolumn{2}{|c|}{ Date $1 / 19 / 98$} \\
\hline \multirow{2}{*}{\multicolumn{4}{|c|}{ Therma] Model of the Whole Element Furnace }} & \multicolumn{2}{|c|}{ EDT No. 608766} \\
\hline & & & & \multicolumn{2}{|l|}{ ECN No. } \\
\hline Name & MSIN & $\begin{array}{l}\text { Text } \\
\text { With All } \\
\text { Attach. }\end{array}$ & Text Only & $\begin{array}{l}\text { Attach./ } \\
\text { Appendix } \\
\text { Only }\end{array}$ & $\begin{array}{c}\text { EDT/ECN } \\
\text { Only }\end{array}$ \\
\hline
\end{tabular}

Fluor Daniel Hanford, Inc.

E. W. Gerber

R3-86 X

Fluor Daniel Northwest
L. J. Garvin
F. F. Fuang
G. A. Ritter
D. A. Smith

$\begin{array}{ll}\text { R3-11 } & \text { X } \\ \text { H5-70 } & \text { X } \\ \text { H0-31 } & \text { X } \\ \text { R3-11 } & \text { X }\end{array}$

Duke Engineering and Services Hanford Inc.
R. B. Baker
S. A. Chastain
D. R. Duncan
J. R. Frederickson
L. A. Lawrence (2)
B. J. Makenas
R. P. Omberg
W. H. Rasin
J. A. Swenson
D. J. Trimble

SNF Project Files

Central Files

$\begin{array}{ll}\text { H0-40 } & \text { X } \\ \text { H0-40 } & \text { X } \\ \text { R3-86 } & \text { X } \\ \text { R3-86 } & \text { X } \\ \text { H0-40 } & \text { X } \\ \text { H0-40 } & \text { X } \\ \text { H0-40 } & \text { X } \\ \text { R3-11 } & \text { X } \\ \text { R3-11 } & \text { X } \\ \text { H0-40 } & \text { X } \\ \text { H0-40 } & \text { X } \\ \text { B1-07 } & \text { X }\end{array}$

Numatec Hanford Company
G. P. Chevrier
E. R. Cramer
T. A. Flament
J. J. Irwin
C. R. Miska
J. P. Sloughter
M. J. Thurgood

$\begin{array}{ll}\text { R3-86 } & \text { X } \\ \text { H0-34 } & \text { X } \\ \text { R3-86 } & \text { X } \\ \text { R3-86 } & \text { X } \\ \text { R3-86 } & \text { X } \\ \text { H5-49 } & \text { X } \\ \text { H0-34 } & \text { X }\end{array}$

Paciic Northwest National Laboratory

J. Abrefah

P7-27 $\mathrm{X}$

S. C. Marschman

P7-27 $X$

SGN Eurisys Services Corp

A. L. Pajunen

R3-86 X

Technical Advisory Group

J. E. DeVine

R. F. Williams

$\mathrm{R} 3-82 \cdot \mathrm{X}$

S7-41 X

U.S. Department of Energy, Richland Operations Office

\begin{tabular}{|c|c|}
\hline R. M. Hiegel & $\$ 7-41$ \\
\hline P. G. Loscoe & \$7-41 \\
\hline E. D. Sellers & S7-41 \\
\hline J. S. Shuen & S7-41 \\
\hline
\end{tabular}

